\title{
Present and future mass balance of the ice sheets simulated with GGM
}

\author{
Atsumu Ohmura, Martin Wild \\ Geographisches Institut, Eidgenössische Technische Hochschule, Winterthurerstrasse 190, CH-8057 Zürich, Switzerland \\ LENNART BENGTSSON \\ Max-Planck-Institut für Meteorologie, Bundestrasse 55, D-20146 Hamburg, Germany
}

\begin{abstract}
A high-resolution GCM ECHAM3T106 was used to simulate the climates of the present and of the future under doubled $\mathrm{CO}_{2}$. The ECHAM3 T106 was integrated for an equivalent time of 5 years (1) with the observed SST of the 1980s and (2) with the SST for the $2 \times \mathrm{CO}_{2}$ climate generated from the ECHAM1 T21 coupled transient experiment. The main motivation for using the GCM to simulate the mass balance is the level of skill in simulating precipitation and accumulation recently achieved in the high-resolution GCM experiment. The ablation is computed, based on the GCM internal surface fluxes and the temperature/ablation relationship formulated on the Greenland field data. The two ice sheets show very different reactions towards doubling the $\mathrm{CO}_{2}$. As the decrease in accumulation and the increase in ablation in Greenland cause an annual mean specific mass balance of $-225 \mathrm{~mm}$ (eq. $-390 \mathrm{~km}^{3}$ ), the increase in accumulation and virtually non-melt conditions in Antarctica result in a mean annual specific mass balance of $+23 \mathrm{~mm}\left(\mathrm{eq} .+325 \mathrm{~km}^{3}\right)$. The sum of the mass balance on both ice sheets is equivalent to the annual sea-level rise of $0.2 \mathrm{~mm}$. This experiment shows that other mechanisms for sea-level change, such as the thermal expansion of the sea water and the melt of small mountain glaciers, will remain important in the coming century.
\end{abstract}

\section{INTRODUGTION}

Glacier mass balance has been one of the most important components controlling global sea level. Among all ice masses in the world, the Greenland and the Antarctic ice sheets occupy an important position both in terms of their surface area and ice volume. A new evaluation of the global surface area and volume of glaciers (Table 1) shows that Antarctica presently has an ice-surface area of $13.586 \times 10^{6} \mathrm{~km}^{2}$ and $30.110 \times 10^{6} \mathrm{~km}^{3}$ ice volume. The corresponding quantities for Greenland are $1.756 \times 10^{6}$ $\mathrm{km}^{2}$ and $2.648 \times 10^{6} \mathrm{~km}^{3}$, respectively. In the context of this paper, small ice caps, valley and mountain glaciers on Greenland and Antarctica are included under the ice sheets. This evaluation shows that $97 \%$ of the glacier surface and more than $99.8 \%$ of the glacier-ice volume are in Greenland and Antarctica. The sea-level equivalent of these ice masses is $74.6 \mathrm{~m}$. The total volume of all small glaciers outside Greenland and Antarctica is at most $20 \mathrm{~cm}$ in sea-level equivalent. Both ice sheets are therefore of prime importance in estimating future sea-level change.

The simulation of future mass balance has been made either by assuming constant precipitation or by assuming certain scenarios Oerlemans and others, 1993). Reactions of the Greenland ice sheet have also been investigated in the form of sensitivity tests Kuhn, 1981;
Ambach, 1985). In recent years, it has become possible to simulate the future SST with a coupled transient experiment, which is a prerequisite for computing a detailed condition for a time snapshot. The problem of the coarseness in grids, the necessity for a general circulation model (GCM) experiment has been considerably improved by introducing high-resolution grids. This improvement will certainly increase with the appearance of massive parallel computers. These conditions altogether have made the present snapshot experiments possible. This method is considered to be superior to a mere nesting of a meso-scale model within a coarse-grid GCM, because high-resolution GCM captures smaller structures which may be important for precipitation and surface-heat balance.

\section{GCM EXPERIMENTS}

The present climate was simulated with the ECHAM3 T106 model which has an equivalent grid size of about $120 \mathrm{~km}$. The model was integrated for $5 \frac{1}{2}$ years using the observed boundary conditions of the mid-1980s. This control run was used to test the capability of the high-resolution GCM and also to evaluate the departure of the $2 \times \mathrm{CO}_{2}$ scenario experiment (Arpe and others, 1995). In the second run, the T106 atmospheric model 
Table 1. Present area and volume of glacier ice on the globe

\begin{tabular}{|c|c|c|c|}
\hline Region & $\begin{array}{c}\text { Surface area } \\
10^{3} \mathrm{~km}^{2}\end{array}$ & $\begin{array}{l}\text { Ice volume } \\
10^{3} \mathrm{~km}^{3}\end{array}$ & Source \\
\hline Greenland & 1756 & 2648 & Weidick (1995), Ohmura (1987a) \\
\hline Iceland & 11 & 1 & Björnsson (1986) \\
\hline Canadian Arctic Islands & 152 & 15 & Ommanney (1972) \\
\hline Jan Mayen & $10^{-1}$ & $10^{2}$ & Field $(1975)$ \\
\hline Svalbard & 37 & 4 & Haeberli and others (1989) \\
\hline Zemlya Franza Yosifa & 14 & 1 & Haeberli and others (1989) \\
\hline Novaya Zemlya & 23 & 2 & Haeberli and others (1989) \\
\hline \multicolumn{4}{|l|}{ Severnaya Zemlya and } \\
\hline Ostrov Ushakova & 19 & 2 & Haeberli and others (1989) \\
\hline \multicolumn{4}{|l|}{ Ostrova de Langa, Ostrov } \\
\hline Vrangelya and others & $10^{-1}$ & $10^{-2}$ & Haeberli and others (1989) \\
\hline North America (continental) & 124 & 12 & Haeberli and others (1989) \\
\hline Scandinavia & 3 & $10^{-1}$ & Östrem and others (1988) \\
\hline Alps & 3 & 0.14 & Chen and Ohmura (1990) \\
\hline \multicolumn{4}{|l|}{ Pyrenees and Cordillera } \\
\hline Cantabrica & $10^{-2}$ & $10^{-3}$ & Haeberli and others (1989) \\
\hline Caucasus & 1 & $10^{-1}$ & Haeberli and others (1989) \\
\hline Ural & $10^{-2}$ & $10^{-3}$ & Haeberli and others (1989) \\
\hline Asia & 92 & 9 & Haeberli and others (1989) \\
\hline Africa & $10^{2}$ & $10^{-3}$ & Hastenrath (1984) \\
\hline New Zealand & 1 & $10^{-1}$ & Haeberli and others (1989) \\
\hline South America & 25 & 3 & Haeberli and others (1989) \\
\hline Sub-Antarctic islands & 7 & 1 & Mercer (1967) \\
\hline Antarctica & 13586 & 30110 & Drewry (1983) \\
\hline Total & 15855 & 32809 & \\
\hline
\end{tabular}
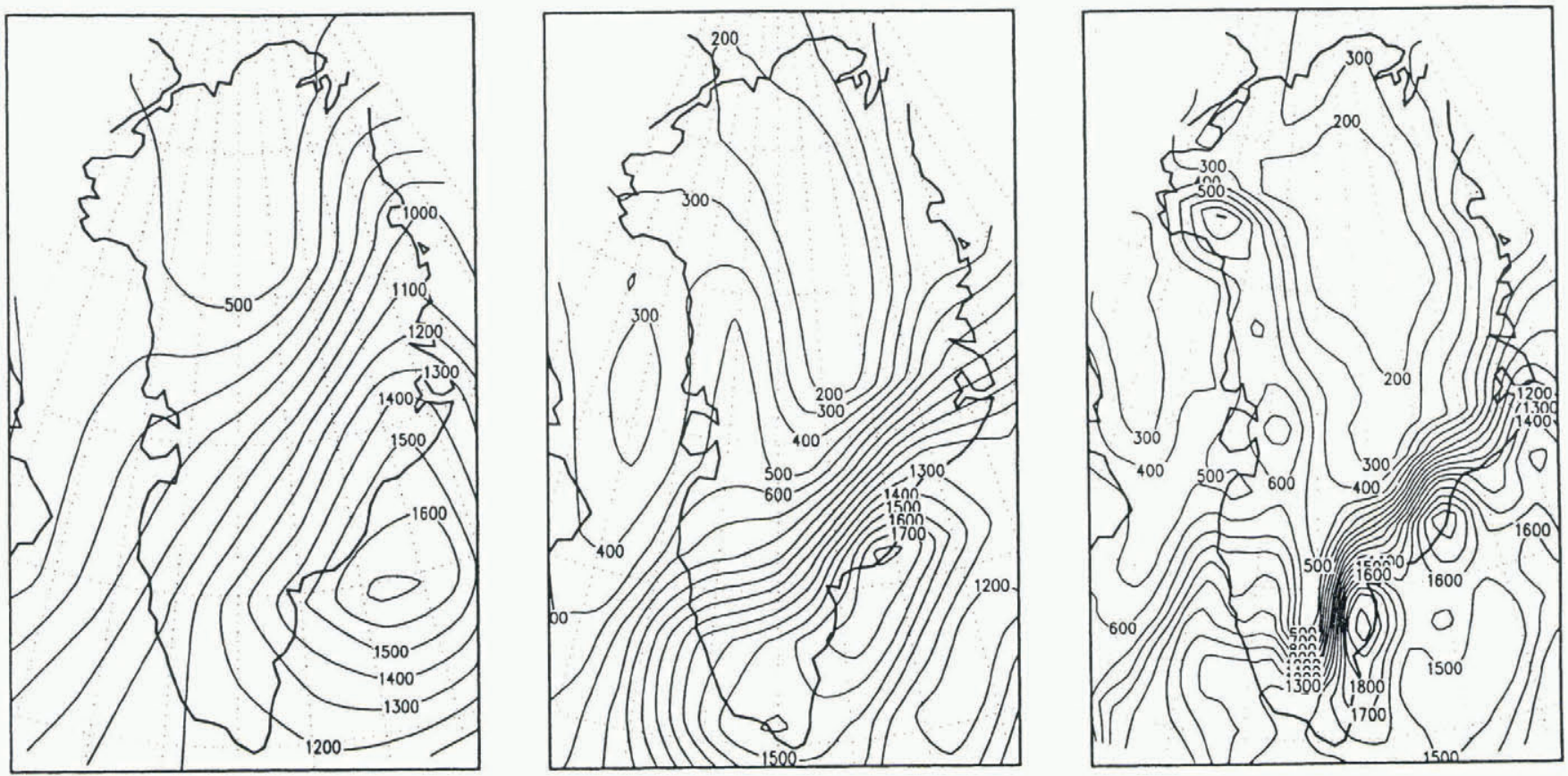

Fig. 1. Annual total precipitation ( $m \mathrm{ma}^{\prime}$ ) simulated by the ECHAM3 GCM with different horizontal resolutions. From left to right, T21, T42 and T106, respectively. 

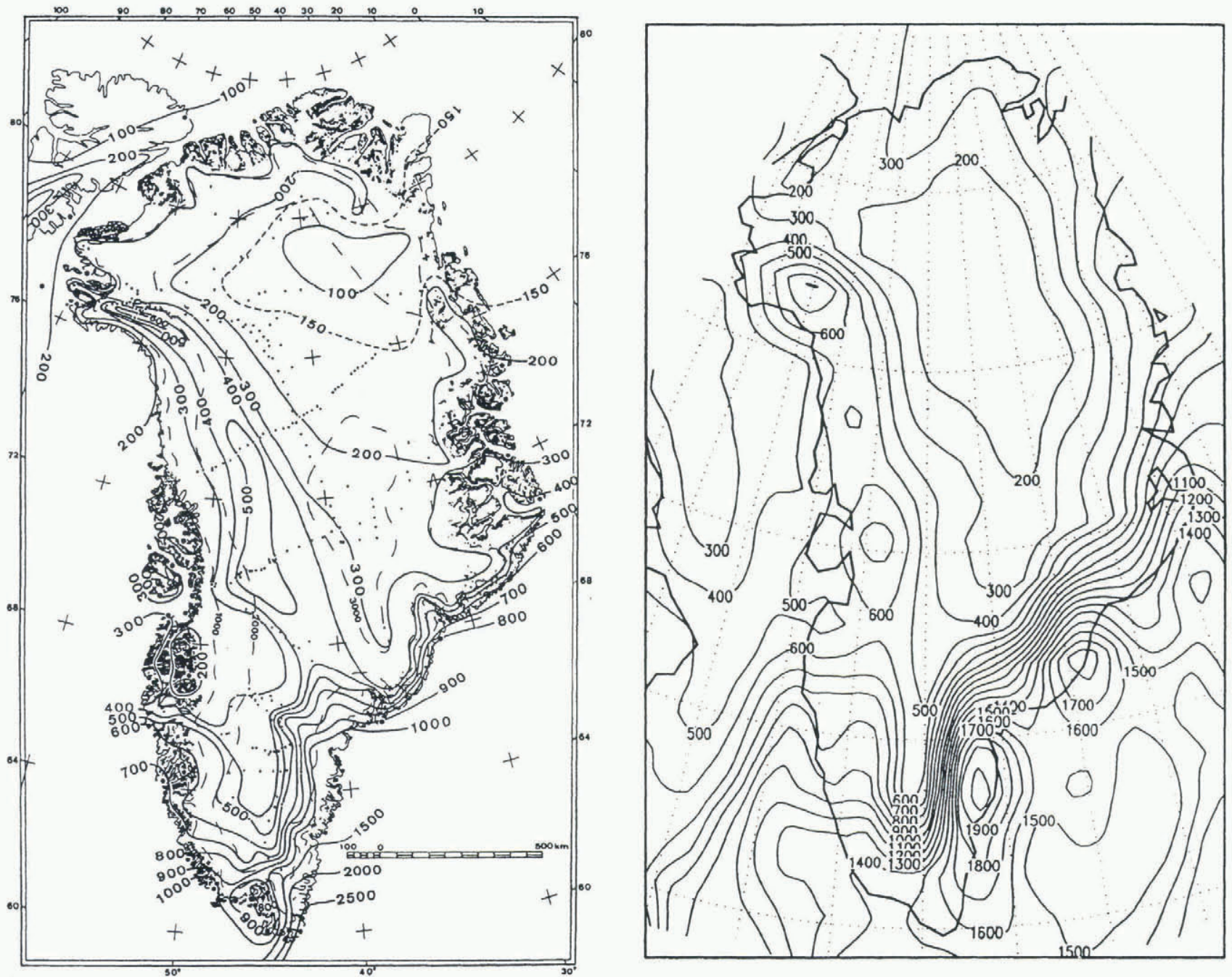

Fig. 2. Comparison of the computed (right) and observed (left) annual total precipitation (mma') for Greenland. The observation is after Ohmura and Reeh (1991).

was integrated for $5 \frac{1}{2}$ years with the prescribed boundary conditions of SST and sea-ice distributions at the time of $2 \times \mathrm{CO}_{2}$ extracted from a low-resolution, fully coupled, atmosphere ocean transient GCM experiment. The $\mathrm{CO}_{2}$ scenario used is IPCC Scenario A Cubasch and others, 1992) and the expected time for $2 \times \mathrm{CO}_{2}$ is $\mathrm{AD} 2045$.

The time domain considered in the present experiment is less than one century. This rather short time span allows one to consider the mass-balance process purely as a surface-exchange phenomenon, without involving dynamic aspects of ice sheets (Abe-Ouchi, 1993).

\section{SIMULATION OF THE PRESENT PRECIPITATION}

The capability of the precipitation simulation increases with the refinement of the horizontal resolution of the model. The sequence of this development is shown in Figure 1 for experiments with T21, T42 and T106 resolution, which give mean precipitation of 785, 585 and $495 \mathrm{~mm}$ year ', respectively. Not only the regional mean but the regional pattern of the precipitation distribution is improved with improvement of the horizontal resolution. As the resolution is increased, the surface topography becomes more realistic. The Atlantic air mass in winter and the Canadian air mass in summer, heading towards Greenland, produce a reasonable amount of precipitation on the steep and realistic ice-sheet margin, preventing an invasion of the excessively moist air mass into the interior, thus also preventing the appearance of the continentalscale overestimation of precipitation. In Figure 2, the T106 comparison with the observed precipitation distribution is presented for Greenland. The occurrence of the highest precipitation on the southeast coast, the sharp latitudinal decline on the southwest coast, the zone of higher precipitation on the west slope, culminating in a maximum north of Melville Bay, and the driest area north of Summit are well represented. After studying other climatic elements, it can be concluded that precipitation is probably the most improved of all elements when the horizontal resolution is increased.

The comparison in Figure 3 also demonstrates that the main features of the precipitation distribution in Antarctica are also well captured by the present model.

More quantitatively meaningful analyses can be made by comparing the accumulation, because what is observed on the ice sheets is accumulation rather than meteorological precipitation (Tables 2 and 3 ). The computed accumulation is defined as the difference between 
Table 2. Components related to the annual mass balance for Greenland (unit mm w.e. $a^{-1}$ )

Observations

$$
340
$$
minus evaporation

3. Annual ablation based on energy balance

4. Annual ablation based on summer temperature

5. Storage change and calving

$$
\begin{aligned}
& 2-3 \\
& 2-4
\end{aligned}
$$

Sources
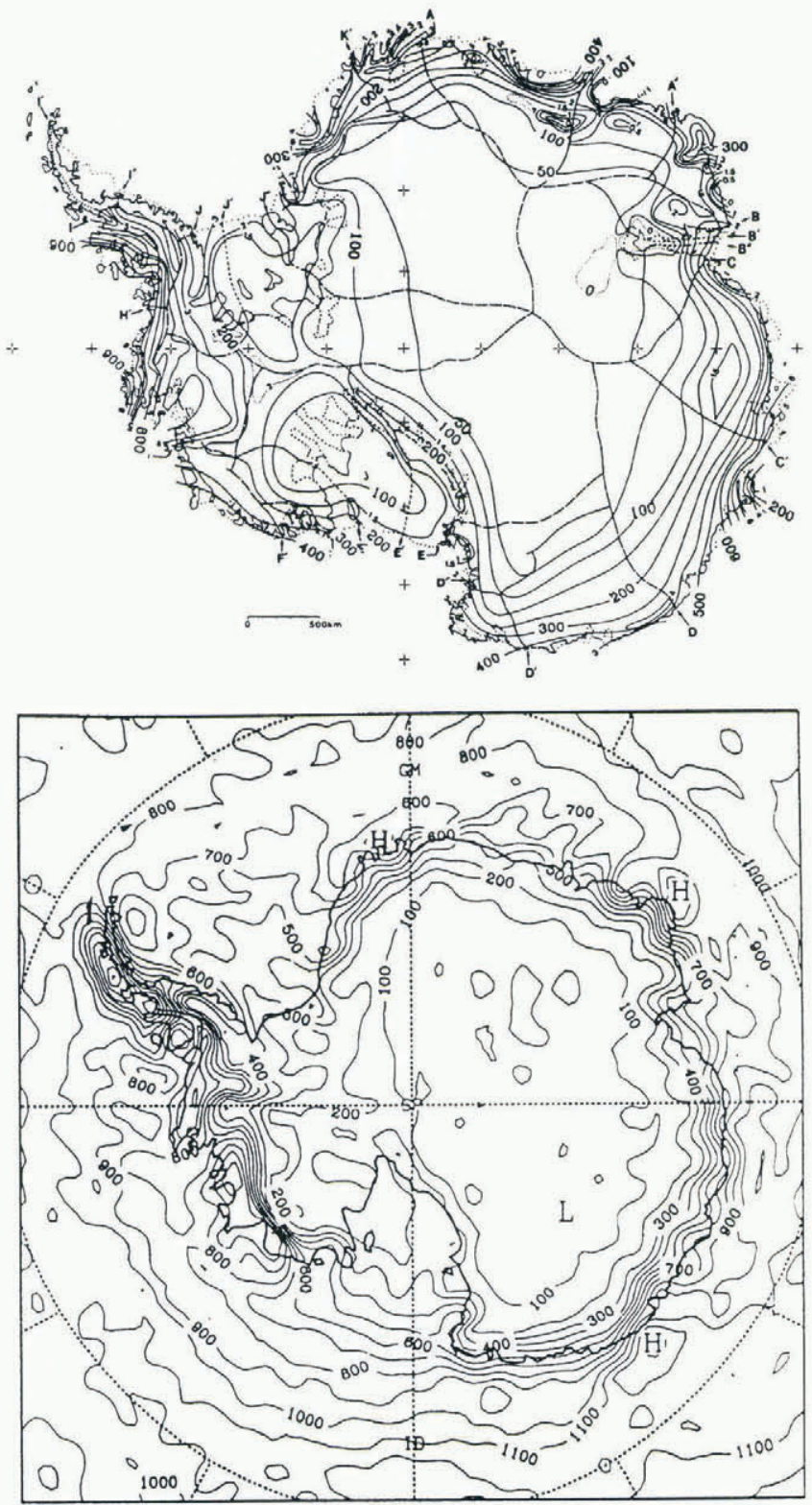

Fig. 3. Comparison of the observed (upper) and computed (lower) annual total precipitation $\left(\mathrm{mma}^{-1}\right)$ for Antarctica. The observed is after Giovinetto and others (1990). the solid precipitation and evaporation, both of which are model computed. This quantity is more directly comparable with the field-observed accumulation, as the evaporative loss is taken into account. For Greenland, there is an average difference of $110 \mathrm{~mm}$ between the observed and the simulated values. The difference is probably not large enough to disqualify the computation, as the observed accumulation evidently represents a somewhat lower value at this stage. Underestimation of the conventional precipitation measurements (Sevruk, 1993) and the drift loss of snow must be added to the observed values. In Antarctica, the simulated value of $197 \mathrm{~mm}$ comes very close to the recent re-evaluation of $184 \pm 37 \mathrm{~mm}$ by Giovinetto and others (1992), in which the drift loss is compensated.

\section{SIMULATION OF FUTURE ACGUMULATION}

Under the doubled $\mathrm{CO}_{2}$ climate, accumulation decreases over slightly more than half of the Greenland surface (Fig. 4). A strong decrease of more than $100 \mathrm{~mm}$ is projected in southeast Greenland. A moderate decrease is seen on the west coast. Synoptically seen the cause of the decrease differs from region to region. The decrease in southeast Greenland is primarily due to the weakening of the Icelandic Low in winter, while the decrease on the west slope is the result of the temperature increase. There is an increase in precipitation and accumulation in the middle and northeast. The increase in northeast Greenland ranges from 50 to $100 \mathrm{~mm}$, a substantial change from the present dry climate in the region. Averaging entire Greenland, annual total precipitation and accumulation decrease by 2 and $21 \mathrm{~mm}$, respectively. This decrease, despite the increase in the moisture content in the air demonstrates the importance of the change in atmospheric circulation in determining the precipitation in Greenland, a feature reported by Kapsner and others (1995), based on the GISP2 ice-core analysis.

Over Antarctica under the doubled $\mathrm{CO}_{2}$ climate, all precipitation is also solid. The largest increase is observed 
Ohmura and others: GCM simulated mass balance of the ice sheets

in the coastal regions where the precipitation is at present large. There is also a large difference between West and East Antarctica, where the increase is 45 and $20 \mathrm{~mm}$, respectively. For entire Antarctica, the increases in precipitation and accumulation are 25 and $23 \mathrm{~mm}$, respectively. The Antarctic ice sheet is located clearly poleward of the sub-polar depression zone. This highlatitude position is the main cause for an increase in precipitation, being more directly influenced by the temperature increase than by the circulation.

\section{SIMULATION OF ABLATION}

The computation of the ablation was done only for Greenland, as the Antarctic ice sheet does not melt under the $2 \times \mathrm{CO}_{2}$ climate. The melt was computed by two methods: the GCM energy balance and the empirical ablation/temperature relationship. With respect to the former method, the annual sum of net radiation, sensibleand latent-heat fluxes were equated to the total latent heat of fusion for the year. This assumption is justified, as the annual total heat conduction is practically zero. The results of the computation were compared against the observations made at ETH Camp in the 1991 summer. The melt amounts computed by the GCM and observed by the micrometeorological heat-balance method (Ohmura and others, 1994) are 66.5 and $58.1 \mathrm{~cm}$ w.e., respectively. When the evaporative loss is added, the GCM and the micrometeorological observations yield total ablations of 68 and $60 \mathrm{~cm}$ w.e., respectively. During the same period, the glaciologically determined ablation was $35 \mathrm{~cm}$ w.e.,
Table 3. Comparison of the GCM-computed and observed annual accumulation for Antarctica

Annual accumulation for Antartica

$\mathrm{mm}$

Model

ECHAM3 T106

$197^{\ddagger}$

Observed

Budd and Smith (1985) 126

Giovinetto and Bull (1987) 143

Bromvich (1990)

$151-156$

Peixoto and Oort (1983)

Giovinetto and others (1992)

$184 \pm 37$

Yamazaki (1994)

135

$\ddagger$ Annual solid precipitation, $224 \mathrm{~mm}$, minus sublimation,
$27 \mathrm{~mm}$

mainly due to the growth of supra-imposed ice, to which the water from higher altitudes evidently contributed. Although this comparison was made only for one site, the present result indicates the GCM's capability of simulating glacier ablation. The distributions of the ablation and the mass balance are presented in Figure 5.

The second method is based on the observed relationship between the annual ablation observed with the glaciological mass-balance method and the mean air
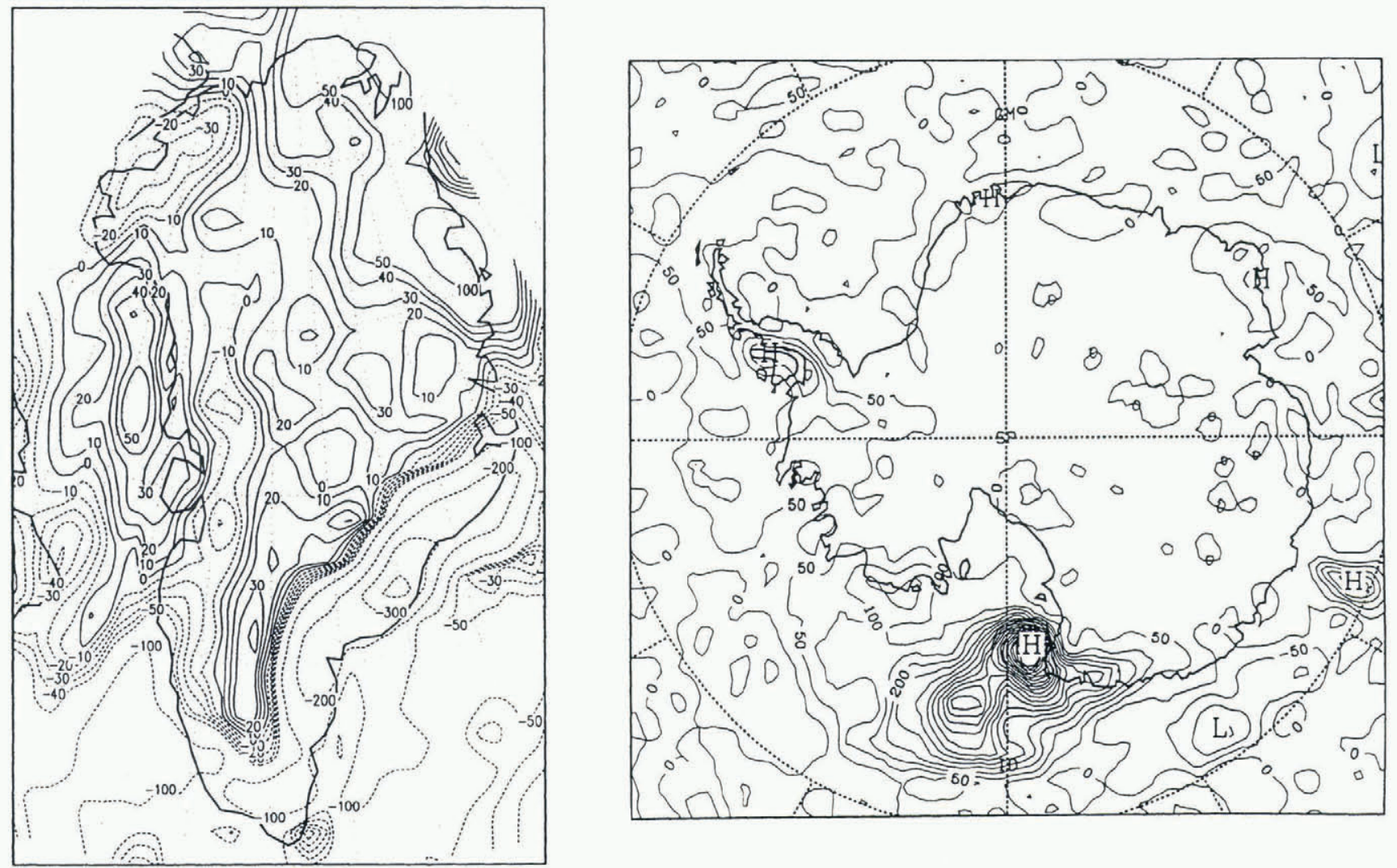

Fig. 4. Change in accumulation for Greenland and Antarctica in $\mathrm{mma}^{-1}\left(2 \times \mathrm{CO}_{2}\right.$ minus $\left.1 \times \mathrm{CO}_{2}\right)$. 

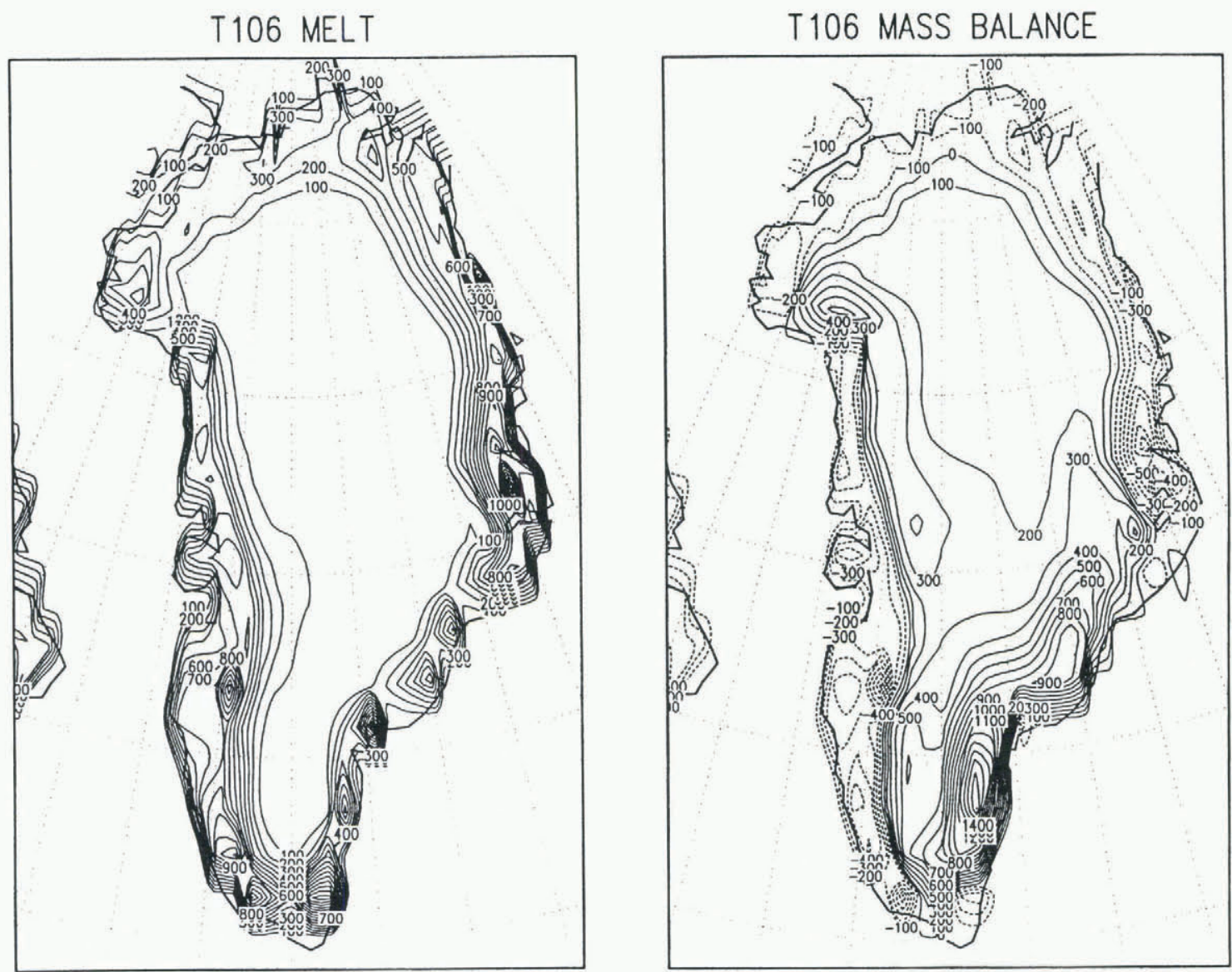

Fig. 5. Distribution of the GCM-simulated annual ablation and mass balance under the present climate for Greenland. Units are in $\mathrm{mm} \mathrm{a}^{-1}$.

temperature of the three summer months, June, July and August, at the same locations as presented in Figure 6. Based on this relationship, the present and future ablations are computed with the temperature distribution of Ohmura (1987b) and the GCM-generated air temperature, respectively. The future increase in ablation due to the doubling of $\mathrm{CO}_{2}$ was also estimated using the GCM-computed temperature.

\section{FUTURE CHANGE IN MASS BALANCE}

The ablation towards the middle of the next century in Greenland increases substantially. The increase in annual ablation is estimated at $197 \mathrm{~mm}$ based on the energybalance method, and $208 \mathrm{~mm}$ based on the ablation/ temperature relationship. Remarkably, the two very different methods give an almost identical result. The change in mass balance in Greenland is characterized by a small decrease in mean annual specific accumulation $(21 \mathrm{~mm})$ and by a substantial increase in mean specific ablation (197-208 mm). Based on this result, Greenland will lose annually about $390 \mathrm{~km}^{3}$ water into the ocean. Antarctica, on the other hand, will gain $325 \mathrm{~km}^{3}$ from the ocean due to the increase in accumulation. The net annual discharge of both ice sheets, $65 \mathrm{~km}^{3}$, is equivalent to an annual sea-level rise of $0.18 \mathrm{~mm}$. This situation makes other factors, such as thermal expansion of sea water and the melt of small glaciers (Meier, 1984), important in the coming century.

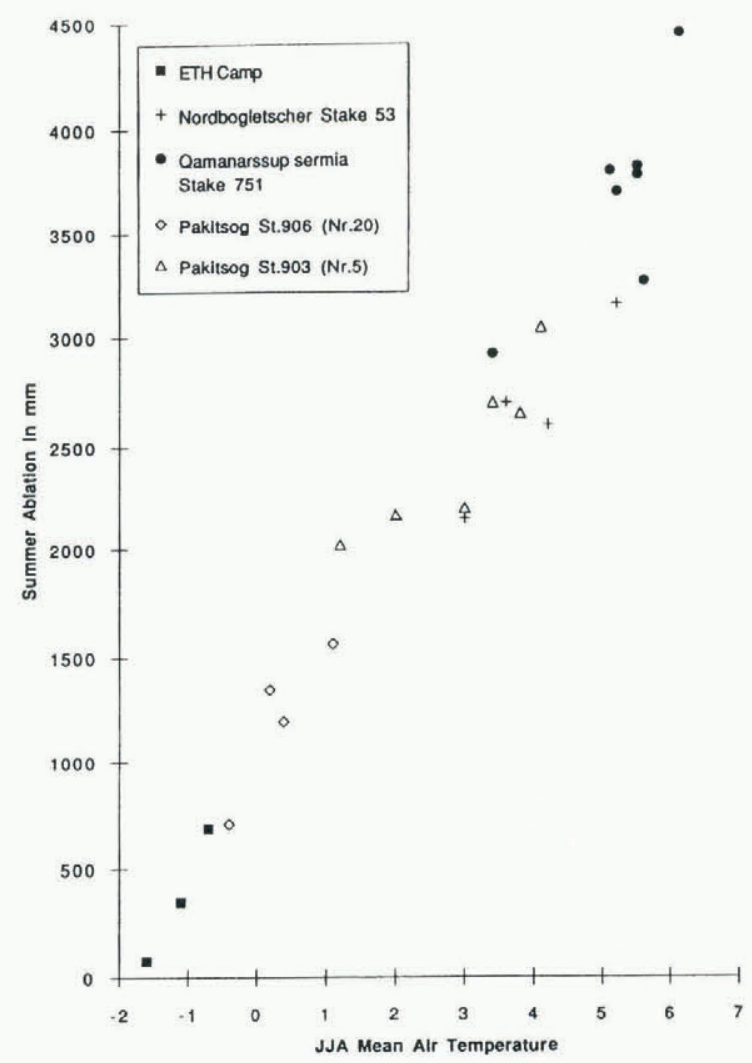

Fig. 6. Relationship between the annual total ablation and the mean air temperature for June, Fuly and August for Greenland. The ablation and temperature data for stations except for ETH Camp have been provided by H. Thomsen and $R$. Braithwaite, respectively. 


\section{CONCLUSION}

A high-resolution GCM, ECHAM3 T106 was found to simulate the surface mass and energy balance of the ice sheets with unparalleled accuracy. The numerical experiments under the present and the $2 \times \mathrm{CO}_{2}$ climates show how differently both ice sheets will react towards the future climate change. As Greenland is predicted annually to lose about $225 \mathrm{~mm}$ w.e., Antarctica will receive $23 \mathrm{~mm}$ more than at present. The combined effect of the mass-balance changes on the sea-level change is to cancel each other. This situation increases the effect of other factors, such as thermal expansion of sea water and the mass balance of smaller glaciers on the sea level. The change in sea level into the middle of the next century will be considerably smaller than previously speculated.

\section{ACKNOWLEDGEMENTS}

The authors express a deep sense of thanks to Drs E. Roeckner and $\mathrm{K}$. Arpe of Max-Planck-Institut für Meteorologie for valuable comments on the GCM experiments. Dr M. Beniston and Dr U. Schlese played an important role in installing the model in the NEC SX3 supercomputer at the Swiss Scientific Computing Centre (CSCS) in Manno. Invaluable support provided by the CSCS members, especially by $\operatorname{Dr} \mathrm{A}$. Bernasconi is appreciated. The present work was financed by the Swiss National Science Foundation, through grants Nos 4031033250 and 5001-35179 for climate modelling. The field experiment was supported by the Swiss National Science Foundation, through grant Nos 20-29822690 and 203264911, and an ETH research fund for the ETH Greenland Expedition.

\section{REFERENCES}

Abe-Ouchi, A. 1993. Ice sheet response to climate changes: a modelling approach. Zürcher Geogr. Schr. 54.

Ambach, W. 1985. Climatic shift of the equilibrium line: Kuhn's concept applied to the Greenland ice cap. Ann. Glaciol., 6, 76-78.

Arpe, K., L. Bengtsson, L. Dümenil and E. Roeckner. 1995. The hydrological cycle in the ECHAM3 simulations of the atmospheric circulation. In Desbois, M. and F. Désalmand, eds. Global precipitation and climate change. Berlin, etc., Springer-Verlag, 361-377. (NATO ASI Series I: Global Environmental Change 26.

Björnsson, H. 1986. Surface and bedrock topography of ice caps in Iceland, mapped by radio echo-sounding. Ann. Glaciol., 8, 11-18.

Bromwich, D. H. 1990. Estimates of Antarctic precipitation. Nature, $3436259)$, 627-629.

Budd, W.F. and I. N. Smith. 1985. The state of balance of the Antarctic ice sheet. In Glaciers, ice sheets, and sea level: effect of a $\mathrm{CO}_{\mathrm{g}-}$ induced climatic change. Report of a Workshop held in Seattle, Washington, September 13 15, 1984. Washington, DC, US Department of Energy. Office of Energy Research, 172-177. Attachment 9, Report DOE ER/60235-1.

Chen, J. and A. Ohmura. 1990. Estimation of Alpine glacier water resources and their change since the 1870 's. International Association of Hydrological Sciences Publication 193 (Symposium at Lausanne $1990-$ Hydrology in Mountainous Regions. I-Hydrological Measurements; the Water (ycle), 127135.
Cubasch, U. and 6 others. 1992. Time-dependent greenhouse warming computations with a coupled ocean-atmosphere model. Climate Dyn., 8, $55-69$.

Drewry, D.J., ed. 1983. Antarctica: glaciological and geophysical folio. Cambridge, Scott Polar Research Institute.

Field, W. O. 1975. Mountain glaciers of the Northern Hemisphere. Hanover, NH, American Geographical Society. Department of Exploration and Field Research, and U.S. Army Corps of Engineers. Cold Regions Research and Engineering Laboratory. (ADA-014532 (Vol. 1), ADA-014533 (Vol. 2), ADA-014534 (Atlas).)

Giovinetto, M. B. and C. Bull. 1987. Summary and analysis of surface mass balance compilations for Antarctica, 1960-1985. Byrd Polar Research Cienter Report 1.

Giovinetto, M. B., N. M. Waters and C. R. Bentley. 1990. Dependence of Antarctic surface mass balance on temperature, elevation, and distance to open ocean. J. Geophys. Res., 95 (D4), 3517-3531.

Giovinetto, M. B., D. H. Bromwich and G. Wendler. 1992. Atmospheric net transport of water vapor and latent heat across $70^{\circ} \mathrm{S} . \mathcal{J}$. Geophys. Res., 97 (D1), 917-930.

Haeberli, W., H. Bösch, K. Scherler, G. Ostrem and C. C. Wallén, Comp. 1989. World Glacier Inventory, Status 1988. Wallingford, etc., IAHS, UNEP \& UNESCO.

Hastenrath, S. 1984. The glaciers of equatorial East Africa. Dordrecht, etc., D. Reidel Publishing Co.

Kapsner, W. R., R.B. Alley, C.A. Shuman, S. Anandakrishnan and P. M. Grootes. 1995. Dominant influence of atmospheric circulation on snow accumulation in Greenland over the past 18,000 years. Nature, $373(6509), 52-54$.

Kuhn, M. 1981. Die Reaktion der Schneegrenze auf Klimaschwankungen. Z. Gletscherkd. Glazialgeol., 16 2), 1980, 241254.

Meier, M. F. 1984. Contribution of small glaciers to global sea level. Science, 226 4681), 1418-1421.

Mercer, J.H. 1967. Southern Hemisphere glacier atlas. Natick, MA, U.S. Army Natick Laboratories. Earth Sciences Laboratory. (Technical report $67-76$-ES.

Oerlemans, J., R. S. van de Wal and L. A. Conrads. 1993. A model for the surface balance of ice masses: Part II. Application to the Greenland ice sheet. Z. Glelscherkd. Glazialgeol., 27/28, 1991/1992, 85 96.

Ohmura, A. 1987a. Heat budget of the climate system between the last glacial maximum and the present. Bull. Dep. Geogr. Univ. Tokyo, 19, 21-28.

Ohmura, A. 1987b. New temperature distribution maps for Greenland. Z. Gletscherkd. Glazialgeol., $23(1), 145$.

Ohmura, A. and N. Reeh. 1991. New precipitation and accumulation maps for Greenland. J. Glaciol., 37(125), 140-148.

Ohmura, A. and 6 others. 1994. Energy balance for the Greenland ice sheet by observation and model computation. International Association of Hydrological Sciences Publication 223 Symposium at Yokohama 1993 - Snow and Ice Covers: Interactions with the Atmosphere and Ecosystems), 85-94.

Ommanney, C.S. L. 1972. Application of the Canadian glacier inventory to studies of the static water balance. 1. The glaciers of Vancouver Island. In Adams, W. P. and F. M. Helleiner, eds. International Geography 1972. Vol. 2. Toronto, Ontario, University of Toronto Press, 1266-1268.

Östrem, G., K.D. Selvig and K. Tandberg. 1988. Allas over breer i SörNorge. Oslo, Norges Vassdrags- og Energiverk, Vassdragsdirektoratet. Hydrologisk Avdeling. (Meddelelser 61. .)

Peixoto, J.P. and A. H. Oort. 1983. The atmospheric branch of the hydrological cycle and climate. In Street-Perrott, A., M. Beran and R. Ratcliffe, eds. Variations in the global water budget. Dordrecht, etc., D. Reidel Publishing Co., 5 - 66.

Sevruk, B. 1993. Checking precipitation gauge performance. In Couling, S., ed. Measurement of airborne pollutants. Oxford, Butterworth Heinemann, 85-107.

Weidick, A. 1995. Greenland, with a section on Landsat images of Greenland by Richard S. Williams, Jr and Jane G. Ferrigno. U.S. Geol. Surv. Prof. Pap. 1386-C.

Yamazaki, K. 1994. Moisture budget in the Antarctic atmosphere. International Association of Hydrological Sciences Publication 223 (Symposium at Yokohama 1993 - Snow and Ice Covers: Interactions with the Atmosphere and Ecosystems), 61-67. 